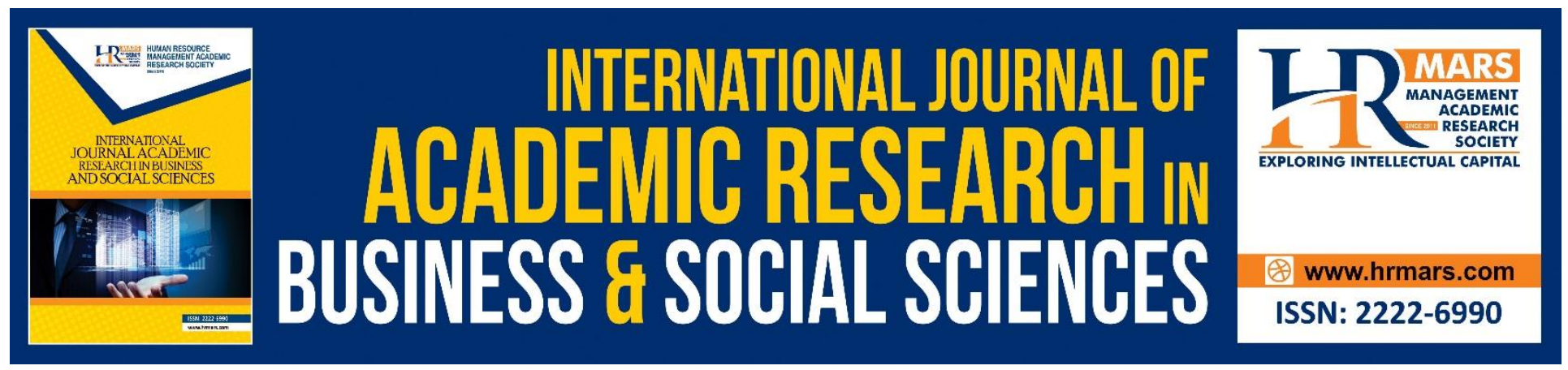

\title{
Information and Communication Technology, Production and Economic Growth: A Theoretical Nexus
}

Masoud Mohammed Albiman, Zunaidah Sulong

To Link this Article: http://dx.doi.org/10.6007/IJARBSS/v8-i12/5062

DOI: $10.6007 /$ IJARBSS/v8-i12/5062

Received: 09 Nov 2018, Revised: 23 Dec 2018, Accepted: 27 Dec 2018

Published Online: 29 Dec 2018

In-Text Citation: (Albiman \& Sulong, 2018)

To Cite this Article: Albiman, M. M., \& Sulong, Z. (2018). Information and Communication Technology, Production and Economic Growth: A Theoretical Nexus. International Journal of Academic Research in Business and Social Sciences, 8(12), 642-657.

Copyright: (C) 2018 The Author(s)

Published by Human Resource Management Academic Research Society (www.hrmars.com)

This article is published under the Creative Commons Attribution (CC BY 4.0) license. Anyone may reproduce, distribute, translate and create derivative works of this article (for both commercial and non-commercial purposes), subject to full attribution to the original publication and authors. The full terms of this license may be seen

at: http://creativecommons.org/licences/by/4.0/legalcode

Vol. 8, No. 12, 2018, Pg. 642 - 657

http://hrmars.com/index.php/pages/detail/IJARBSS

JOURNAL HOMEPAGE

Full Terms \& Conditions of access and use can be found at http://hrmars.com/index.php/pages/detail/publication-ethics 


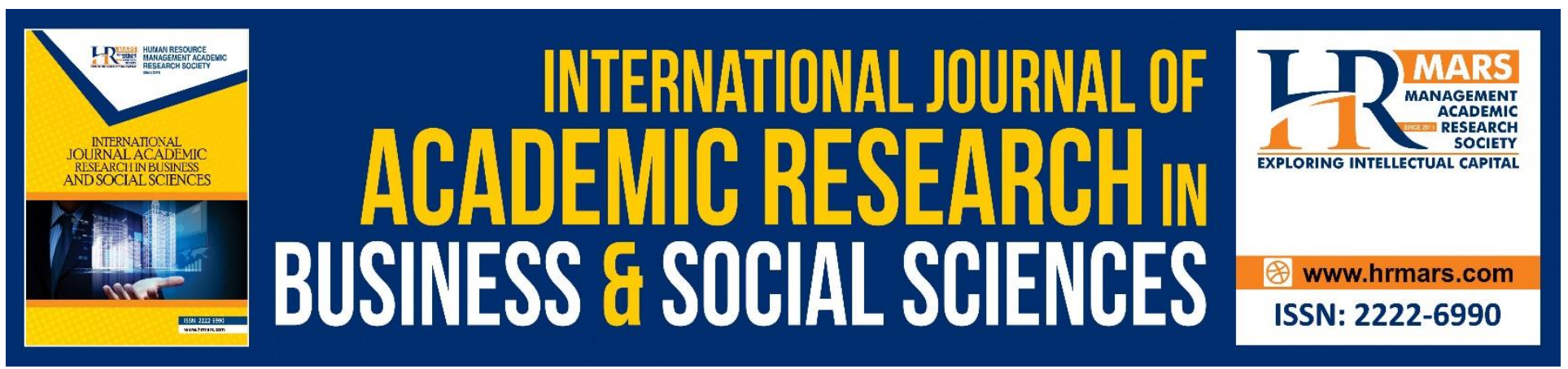

\title{
Information and Communication Technology, Production and Economic Growth: A Theoretical Nexus
}

\author{
Masoud Mohammed Albimann, Zunaidah Sulong ${ }^{\mathrm{b},{ }^{*}}$ \\ aanzibar Revenue Board (ZRB), Zanzibar, Tanzania \\ ${ }^{\mathrm{b}}$ Faculty of Economics and Management Sciences, Universiti Sultan Zainal Abidin, Terengganu, \\ Malaysia \\ *Corresponding Email: zunaidah@unisza.edu.my
}

\begin{abstract}
This paper explains the relationship between information and communication technology (ICT), production and economic growth. The main intention is to highlight the theoretical relationship between ICT and economic growth within an economy. Five subsections will be discussed including Zhen-Wei Qiang, Pitt and Ayers framework, total impact of ICT on economic growth, complementary effect of ICT on economic growth, ICT network externalities and last one is the empirical literature recapitulation. The chapter concludes that the gaps identified will open up the need for extensive research in this field, hoping to provide guidelines to developing countries in terms of policy directions and future planning.
\end{abstract}

\section{Introduction}

Information and communication technology (hereafter, ICT) refers to communication device including computers, mobile phone and fixed telephone. ICT can be defined as technologies which enable the process of communication and distribution as well as easy access to information. ICT basically includes fixed telephone lines, mobile devices, the internet and personal computers. The International Telecommunication Union (ITU, 2012) defines ICT as a tool that increases efficiency in the technological development resulting in revolution in the world of production and logistics as well as in the decision making of firms. The effects of the information development span the whole process of day to day activities, and play an important role in the government, business and individual settings.

A notable economic development that happened in global economies; especially in developed economies during 1980s and 1990s, was the rapid increase in the ICT sector's share of investment 
and economy. According to ITU (2015; 2014; 2012), the adoption ICT became an integral part of strategic planning for many organizations in developing countries, seeking to engage in the emerging digital economy. ICT plays an important role in revolutionizing management structure and nature of competition in emerging economies. In theory, the use of ICT promotes sustainable and independent economic structure in any given country. Poor structures and policies governing the economy, as well as existence of investment and productivity gaps may lead to unsustainable economic development in the African countries.

In September 2015, United Nations (UN) has established the new Sustainable Development Goals (SDGs) which identifies 17 goals with specific targets to be achieved in the next 15 years (by 2030). Some of the targets include reducing poverty and hunger, increasing decent employment, ensuring development, innovation and infrastructure in the industry. Globally, mobile connectivity has already connected 4.7 billion people, enabling communications between rural and urban areas, easing transfer of goods and services, thus boost the economy. Moreover, it helps to improve health care, education services, agricultural and financial inclusion, indirectly alleviating poverty and ensuring more sustainable development (GSMA, 2016).

The use of mobile communication services helps solve the problem of communication failures in government agencies. Among them is it allows access to health information and speeds up the relay of price information for agricultural products resulting in improved development of other sectors in the economy. Moreover, ICT promotes innovation such as mobile money transfers and money remittances.

Empirical literature showed different results that remain debatable regarding the use of ICT. These studies can be grouped into four different findings. The first group proved that the use and investment in ICT facilitate the process of development, in social, political and economic perspectives, in both developed and developing countries (Gordon 1999; Jorgenson, 2001, Jorgenosn et al., 2002; Jorgensen and Stiroch, 2005; Czernich et al. 2009; Seki, 2008; and Koutroumpis 2009; Ward and Zheng, 2016; Kumar et al., 2015a). This is in fact what the majority believe.

The second argued that the use and investment of ICT especially in developing countries would not guarantee economic development unless there are complementary factors such as infrastructure, enabling policies, financial development, human capital and production innovation in play (Caroli and Van Reenen, 2001; Brynjolfsson et al., 2002; Conway et al., 2006; Samoilenko and Osei-Bryson, 2008; Van Reenen et al., 2010; Adrianaivo and Kpodar, 2011; Ana F and Carmen, 2012; Sassi and Goaied , 2013; Jin and Cho, 2015).

The third found no impact of ICT on growth and productivity (Roach 1987;1991; Loveman 1988; and Baily and Chakrabarti 1988; Lee et al., 2005; Erumban and Das, 2016) while the fourth actually found a negative impact of ICT on economic growth (Freeman and Soete, 1985, 1994, 1997; Aghion and Howitt, 1998). The debate among the economists on the impact of ICT use and investment on economic growth remains but many believe that with the right infrastructure and training, economic growth is imminent, more so in developing countries than the developed ones. 


\section{Zhen-Wei Qiang, Pitt and Ayers Framework}

Tarute and Gatautis (2014) and Consoli (2012) summarized theories regarding the role that is played by ICT on firms' productivity and economic growth. The theoretical literature has spread more widely, analyzing the impact of ICT from the macro to the microeconomic level. This part will explain the connection from the micro level to the macro level. Consoli (2012) categorized main effects of ICT into four main groups namely performance, expansion, new products and growth (Figure 1.1). Each group consists of several dimensions as shown in Figure 1.1.

(1) Performance: The use of ICT leads to reduced cost of supply and communications by firms, thus increases efficiency and effectiveness of the firms. The more the firms become efficient and effective, the more competitive they are in the market in terms of pricing, marketing and securing sales. It also enables firms to be innovative through exchange of information with related institutions and organizations.

(2) Expansion: ICT eases expansion of an organization by improving domestic and international communications and improving every level of production, even from the level of supply chain. ICT usage, particularly in the form of internet marketing increases exposure of an organization to the world, attracting business cooperation and strategic alliance. The use of ICT is also expected to contribute into these five aspects of good business strategies; increased flexibility via products and services differentiation, better visibility, better information provision, online transaction facility and online marketing strategy.

(3) New products: ICT leaves a large impact on new products or services, screaming for its inclusion in the perks offered. The information offered by the internet these days makes it hard to design new products without taking into consideration what is already offered by other similar product. Newer product should be able to offer similar or better features in order to really compete in the market. Customer satisfaction is pertinent as even the slightest dissatisfaction would not escape the scrutiny of web users and good reviews could bring a product a fair distance.

(4) Growth: Growth takes place when firms invest in ICT for business purposes and productivity increases. This could happen through reduction in marginal cost of production, but more can be achieved through sales boost, opening in new market opportunities and exposure via advertisement and websites.

Maciulyte-Sniukiene and Elina Gaile-Sarkene (2014) summarized theoretical impact of ICT on productivity. By referring to Zhen-Wei Qiang, Pitt and Ayers' (2003) model, they explained channels available for ICT to drive economic growth and labour productivity.

i) TFP growth in sector producing ICT: the ICT revolution is partly characterized by rapid technological progress leading to rapid use of ICTs in ICT producing sectors. The technological progress results in higher productivity which in turn improves the average TFP growth. 
ii) Capital deepening and ICT can influence productivity when there is high level of investment. The use of information and communication technologies lead to reduced cost of operations and reduced relative price of goods. As price of goods declines, the real capital output per worker increases (capital deepening in the macro economy). This would complement other factors, ultimately results in increased per capita productivity of the existing capital stock and labor in the economy.

iii) TFP grows through reorganization and ICT usage. The advancement in the use of ICT can enhance new business models making them more productive and more efficient in disseminating information cheaply, with less administrative bureaucracy. In turn, the process of production throughout the economy becomes more effective and efficient. This results in reorganization of markets for goods and services, new product initiation and an improved economy. 
INTERNATIONAL JOURNAL OF ACADEMIC RESEARCH IN BUSINESS AND SOCIAL SCIENCES

Vol. 8, No. 12, Dec, 2018, E-ISSN: 2222-6990 @ 2018 HRMARS

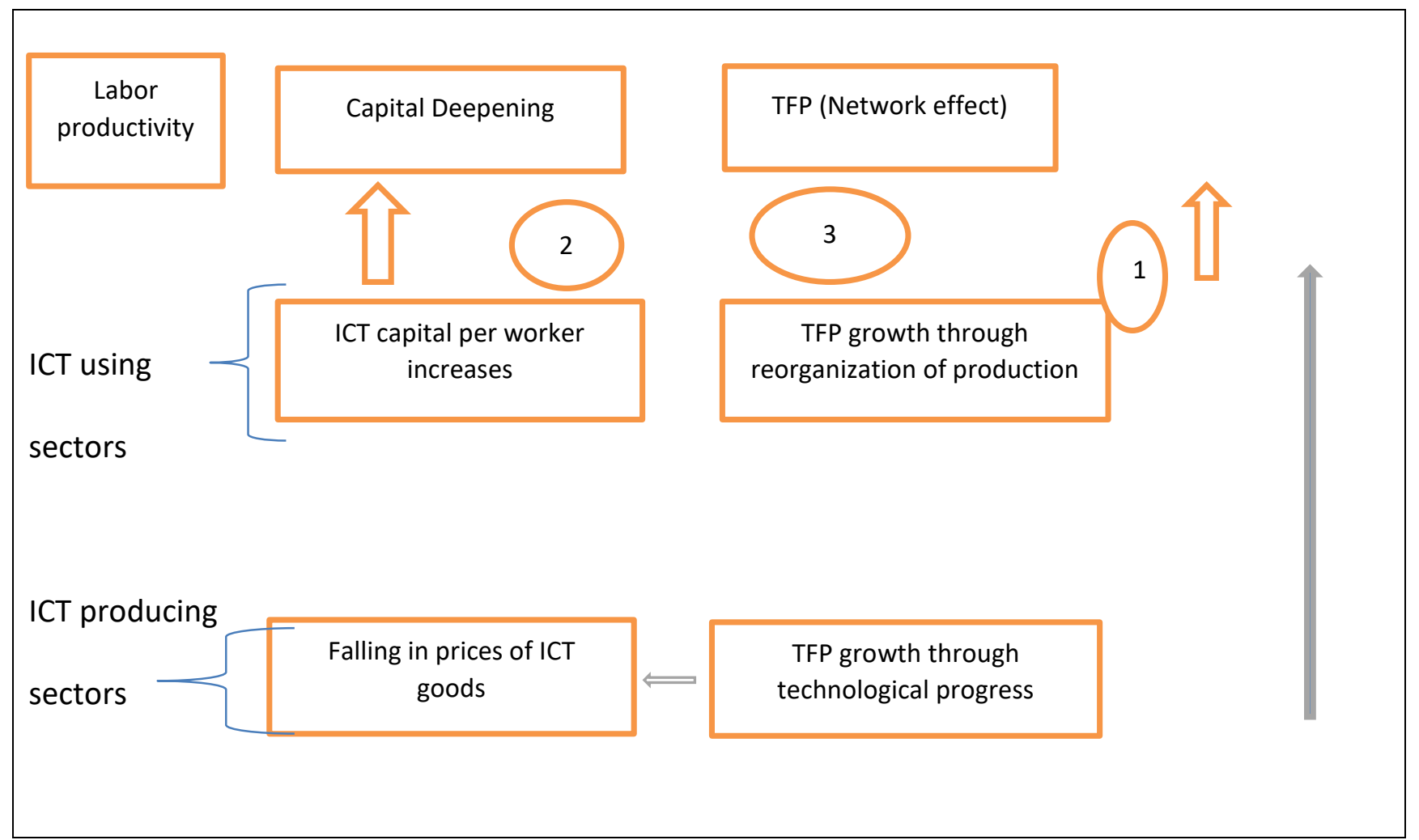

Figure 1.1: Theoretical impact of ICT on productivity (Source: Adapted from Zhen-Wei Qiang, Pitt and Ayers (2003), as cited from Maciulyte-Sniukiene and Elina Gaile-Sarkene, 2014)

\section{Total Impact of ICT on Economic Growth}

Figure 1.2 suggests ICT's direct impact on capital, labor productivity, network effect and multifactorial productivity. In addition, ICT acts as complements to factors including human capital, management and organizational structures, financial system and private sector development. ICT also removes inefficiency and barriers promoting innovation, openness, good service delivery as well as good governance.

Furthermore, Katz (2009) pointed to four ways ICT may benefit an economy: Increased productivity, better employment, creation and reallocation of enterprise and economic growth Economists unanimously believe that ICT not only leave good impact on ICT-related industries but also on non-ICT industries and governance matters (Maciulite-Sniukiene and Gaile- Sarkane, 2014).

Figure 1.2 Total impact of ICT on economic growth. (Source OECD, 2009) 
INTERNATIONAL JOURNAL OF ACADEMIC RESEARCH IN BUSINESS AND SOCIAL SCIENCES

Vol. 8, No. 12, Dec, 2018, E-ISSN: 2222-6990 @ 2018 HRMARS

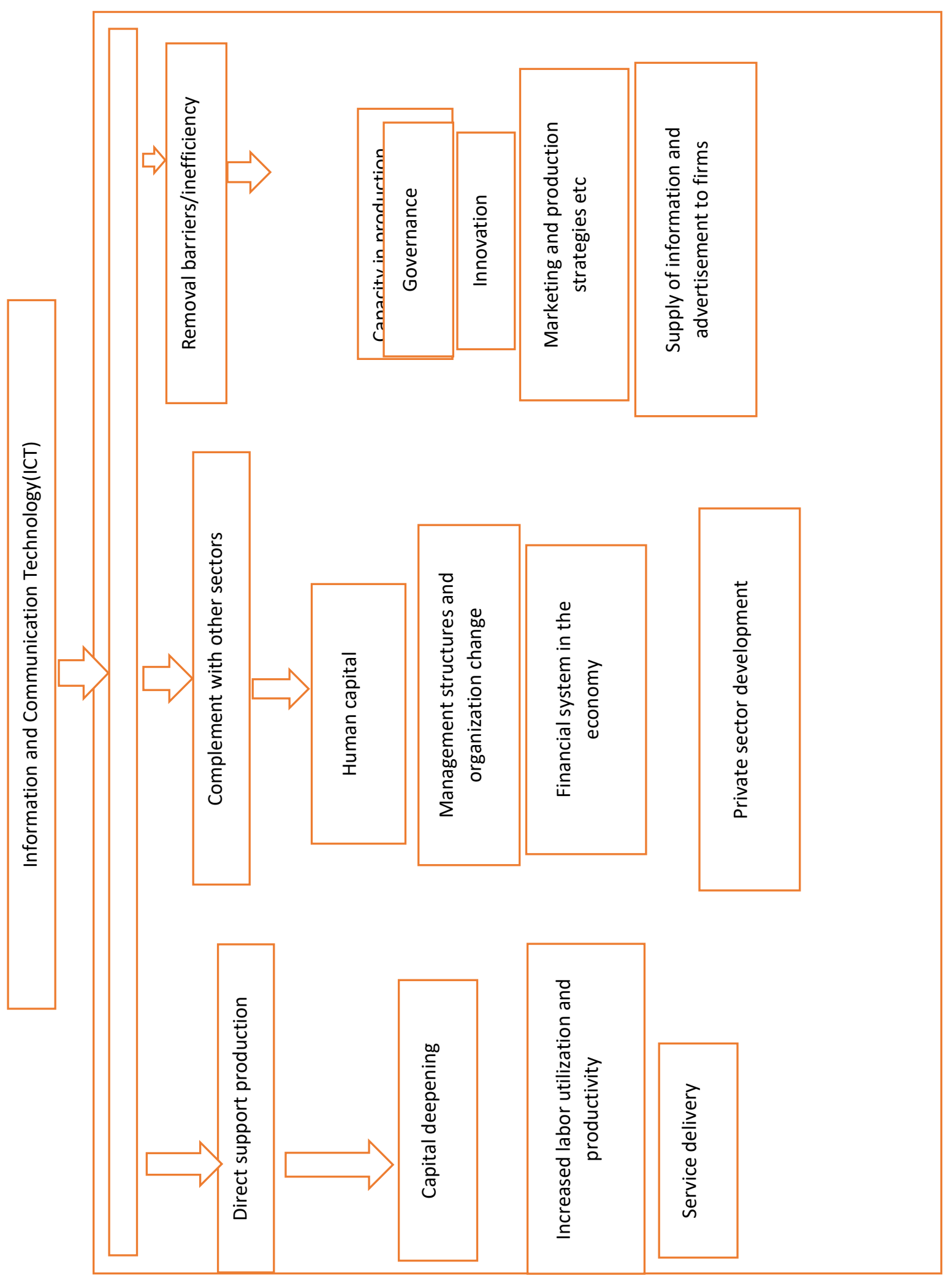




\section{Complementary Effect of ICT on Economic Growth}

In order for firms and economies to benefit from ICT adoption, certain conditions are required to be met. These conditions are termed "complementary hypothesis" whereby the ICT complements other factors in bearing positive impact for the economy. The assumptions propose that:

a) The investment or use of ICT per se, might have very low significant (positive) impact on economic growth or productivity; the impact could even be negative.

b) The full benefit that can be absorbed from ICT is characterized by time lag tendency, which comes from the organizational change that the firms pass through. This can be merged with the explanation in Solow's paradox theory that states: - It takes time to observe the benefits from the use of ICT such as computer. Furthermore, empirical results of the 1990s indicated a large increase in U.S. productivity mainly in the second half of the decade.

c) Substantially positive impact of ICT is only apparent once it complements organizational behavior (i.e., once productivity or economic growth depend on ICT per se). For example, organizational practices have significantly different ways in influencing costs of information gathering and processing. This is indicated in various empirical results obtained in earlier studies between US and EU firms performance, with many pointed to the US firms' managerial role that boosts the economy.

d) Human capital, ICT skilled workers and ICT training for staff determine the magnitude of positive impact ICT brings to productivity and economic growth (without which would result in zero or even negative impact on productivity).

e) The advantage of ICT may vary across different firms. This is because not all firms or sectors are able to implement successful organizational reform in a short period of time. This explains the empirical inter-sector and inter-firm variability findings for impact of ICT on productivity.

f) Government budget for ICT is a significant complement to its positive impact, with most goes to research, development (RandD) and innovation. Such endeavor would allow local firms to reap the potential of ICT at its fullest. This theory is supported by many related studies (Manochehri et al, 2012).

The World Economic Forum in 2015 prepared a measuring tool called Networked Readiness Index (NRI) that measures the propensity of nations to reap the opportunities and benefits offered by ICT. The index includes six main principles, four of them are: The presence of quality business and regulatory environment, ICT readiness, indicated by the presence of ICT infrastructures, its affordability and skills acquired by ICT operators, its impact on individual, society and economy, the interaction among prerequisites (environment, readiness, and usage) by way of reinforcing each other in a virtuous cycle. 


\section{ICT Network Externalities - The Non-Linear Effect}

Arthur (1989) argued that the adoption of modern and complex technologies often offers more experience and improvement which may result in increased productivity. Its effect may increase with better internet broadband or mobile penetration, a condition termed as network externality or network effect (Economides and Himmelberg, 1995). For example, the more people who own mobile phones, the greater the value of the mobile phone to each owner. The effect of ICT may not necessary be linear and more likely to be exponential in nature when threshold is reached (Gruber and Koutrompis, 2010).

The simplest network effect is a direct one, a network effect that takes place upon increased usage. For example, in products or services to customers, the willingness to pay for the last unit of mobile phone or internet would increase if the expected number of users increases (Economides and Himmelberg, 1995). In that sense, the network externality is expected to promote economic growth (Economides and Himmelberg, 1995). The power of ICT network effect on economic growth is gained through its adoption and investment. Thus, an increase in ICT usage, be it mobile phones or internet, would be an incentive for more investment (Gruber and Koutroupis, 2011). Hence, there is a significant difference in impact of ICT between developing and developed countries due to differing ICT penetration between them. Developing countries face low penetration issues resulting in lower investment.

On the other hand, an indirect network effect or externality occurs when the use of one product or network causes an increase in the use of a complementary good which in turn increases the value of the former. The complementary good may be an operating system, a software or an internet application (Wamboye et al., 2015).

Meanwhile, the indirect network effect can also be passed to banking and trading activities as well as productivity which then stimulate economic growth through its effect on technology diffusion and adoption (Wamboye et al., 2015). On top of that, if investment in ICT is predominantly driven by ICT private sector, the network effect dictates the level of innovation or investment and provision of variety of services (Wamboye et al., 2015).

Technology convergence is what transpires in this modern day era, when technologies such as camera, video camera and internet browser are now offered in one platform called mobile phones. This creates an intense competition among mobile phone producers resulting in rapid expansion of the economy-wide information network (Jung, Na and Yoon, 2013).

Subsequently, the rapid expansion of mobile infrastructure and broadband internet mediates the use of ICT across various sectors of a growing economy and brings forth network economies (Jung, $\mathrm{Na}$ and Yoon, 2013). Meanwhile, as the technology convergence intensifies, investment in ICTintensive products and services picks up, establishing a virtuous cycle of cumulative effects between ICT use and investment (Jung, Na and Yoon, 2013). 


\section{Empirical Literature Recapitulation}

The ICT revolution has changed society drastically in the last years of last century. In the mid-1980s and early 1990s, intense work was made to try to quantify the impact of ICT on growth. The debate was first initiated by Solow (1987) when he quipped 'You can see the computer age everywhere but in the productivity statistics'. The rise of Solow paradox prompted debates in 1987. Until early 1990s, the effect of ICT on productivity was still vague, due to the difficulty in measuring and quantifying ICT data.

However, by the turn of the millennium, many studies found benefits and contributions by ICT on productivity. They were mostly concentrated in the US, the EU and the UK concentrating on the micro level. In early 2000s, studies expanded to other developing countries such as the OECD with many confirming positive impact of ICT on productivity and economic growth. However, most of the studies were conducted for developed countries, leaving the developing regions with very few results and unexplored facts. This gap opens up the need for extensive research on developing regions. Briefly, the followings are among the gaps identified in the empirical literatures:

Direct impact of ICT investment on firms and production industries.

The complement factors that mediate the role of ICT in TFP - the role of human capital and organization changes.

Impact of ICT on macro economic performance (GDP).

Role of "ICT investment" in macro economic growth.

Role of "ICT telecommunications use" on the macroeconomic performance.

Non-linear effect of ICT on economic growth (GDP) and TFP.

Other determinants of economic growth - human capital, domestic investment, trade openness, institutional quality and financial development.

\section{Conclusion}

The rise of Solow paradox prompted debates since the 80s. The effect of ICT on productivity was still not confirmed, due to the difficulty in measuring and quantifying ICT data, until early 90s. However, nearing the end of that millennium, many studies started to have similar yet different conclusion, that ICT does have its contribution towards productivity. In 2000s, studies started to rise from many developed countries such as OECD countries confirming the positive impact of ICT on economic growth.

Most studies by then was conducted in developed countries leaving developing countries unexplored for such effect. This gap opens up the need for extensive research in this field, hoping to provide guidelines to developing regions in terms of policy directions and future planning.

On top of that, literature in the last two decades before the millennium examined linear impact (direct impact) of ICT investment, neglecting complements that are vital in its success. Only in the early 2000s that new studies started to examine important factors that complements ICT in order to improve productivity and in turn, economic growth. In fact, most of the micro analysis on firms and industries confirmed that ICT delivers returns to productivity once coupled with some other 
INTERNATIONAL JOURNAL OF ACADEMIC RESEARCH IN BUSINESS AND SOCIAL SCIENCES Vol. 8, No. 12, Dec, 2018, E-ISSN: 2222-6990 C 2018 HRMARS

factors such as human capital and good management. Only a few documented no role played by those factors with ICT in improving productivity.

Another weakness of earlier literature is that they did not consider the use of ICT, perhaps because of unavailability of data to present it at the time. Many used IT/ICT investment as input factors in their models in the form of amount of IT or ICT expenditure or ratio of ICT capital over total capital. In addition to that, most of them were still conducting at micro level such as firms or group of industries.

Furthermore, earlier studies examined the impact of ICT on economic growth using linear assumptions. They merely assumed that ICT has linear effect on productivity. Nevertheless, with the advancement in analysis of ICT's impact, some literature argued upon non-linear effect on productivity and growth. The issue of non-linear effect of ICT is a matter of debates as they try to reveal whether mass penetration of ICT would promote or deteriorate productivity and economic growth. Again, very few studies have examined such analysis on developing regions like the SSA countries.

Literatures within the developing countries (Lee et al., 2012; Kpodar and Adranaivo, 2011; Aker and Mbiti,2010; Alozie et al.,2011, Asongu, 2015; Sassi and Gaoied, 2013; Wamboye et al., 2015) however, relied on the analysis of general policy implications ${ }^{1}$. That is to say, they did not consider different income groups or different time periods as they do in developed countries (see for example, Chavula, 2013; Papaioannou and Dimelis; 2007; Yousefi, 2011; and Vu, 2011, 2013). This analysis is worthy to both donors, such as OECD, WB, IMF, UNCTAD, and policy makers to ensure effective policies in African countries

Although many studies in developed region used GMM methods, to the best of the author's knowledge, very few used Pooled Mean Group (PMG). Only Dimelis and Pappainoau (2010) for US and EU industries and Mohyiden, Ismail and Law (2012) for Malaysia utilized PMG method. The method is very important as it may reveal the effect of ICT in the long and short runs, and give policy implications even in small sample of cross sections.

In addition to that, most literature on the SSA used sample data from 1980s to 2007 (see for example, Lee et al.,2012; Chavula, 2013; Kpodar and Adranaivo, 2011; Alozie et al., 2011; Asongu, 2015). This study will include most data as recent as 2014. This means that the data would include critical times in terms of ICT's history and contributions to economic growth.

Meanwhile, this study takes a leap in analysis by using PMG on different groups of income within the SSA, although several studies did utilize GMM, including Wamboye et al. (2015), Kpodar and Adranaivo (2011) and Lee et al. (2012). In fact, the reason behind might be due to narrow

\footnotetext{
${ }^{1}$ Although the study of Chavula (2013) has tried the analysis of different income groups, they differ from our study in terms of method of analysis, number of ICT proxies employed, technique of analysis and not considering the issue of non-linear effect on the economic growth.
} 
interest with inquiry only on general policy implications. Many earlier studies within the SSA region (Asongu, 2015; Chavula, 2013; Alozie et al., 2011) utilized Ordinary Least Square methods (OLS), which is surrounded by limitations like failing to deal with problem of endogeneity in the regression.

This research is expected to avoid several weaknesses of previous studies by examining both linear and nonlinear effects of ICT on economy. The study will also use the technology penetration proxies including mobile phone, fixed telephone and internet subscriptions. Furthermore, the study will examine several potentially ICTs growth-enhancing transmission channels including financial development, human capital, institutional quality and domestic investment. The increase in ICT innovation, uses and investment in the least connected countries (LDCs) which are the home of 2.5 billion people should therefore be the policy focus for years to come.

Thus, there is no doubt that clear understanding regarding direct and indirect impacts on economic growth is vital before any policy recommendation can be made. The analysis on the impact of ICT on economic growth in developing countries is of great importance to the economic planning and policy formulation of the government, academic literature and methodology. 
INTERNATIONAL JOURNAL OF ACADEMIC RESEARCH IN BUSINESS AND SOCIAL SCIENCES

Vol. 8, No. 12, Dec, 2018, E-ISSN: 2222-6990 @ 2018 HRMARS

\section{References}

Aghion, P. and Howitt, P., (1998), Endogenous Growth Theory. Cambridge, MA. MIT Press.

Aker, J. C., and Mbiti, I. M. (2010). Mobile phones and economic development in Africa. The Journal of Economic Perspectives, 24(3), 207-232.

Alozie, N. O., Akpan-Obong, P., and Foster, W. A. (2011). Sizing up information and communication technologies as agents of political development in sub-Saharan Africa. Telecommunications Policy, 35(8), 752-763.

Andrianaivo, M. and Kpodar, K. (2011). ICT, financial inclusion, and growth evidence from African countries, IMF Working Papers, Vol. 11 No. 73, p. 1, doi: 10.5089/9781455227068.001.

Arthur, B. (1989). Competing technologies, increasing returns, and lock-in by historical events. The Economic Journal, 99(394), 116-131.

Asongu, S. A. (2015). How has mobile phone penetration stimulated financial development in Africa? Journal of African Business, 14(1), 7-18.

Baily, M. N., and Chakrabarti, A. (1988). Electronics and white-collar productivity in innovation and productivity crisis. Washington: Brookings.

Brynjolfsson, E., Hitt, L. and Yang, S. (2002). Intangible assets: Computers and organizational capital. Brookings Papers on Economic Activity, Vol.1, pp. 137-98.

Caroli, E., and Van Reenen J. (2001). Organization, Skills and Technology: Evidence from a panel of British and French establishments. The Quarterly Journal of Economics, 1, 1449-1492.

Chavula, H. K. (2013). Telecommunications development and economic growth in Africa. Information Technology for Development, 19 (1), 5-23.

Consoli, D. (2012). Literature analysis on determinant factors and the impact of ICT in SMEs. ProcediaSocial and Behavioral Sciences, 62, 93-97. doi.org/10.1016/j.sbspro.2012.09.016

Conway, P., Steiner, F., Nicoletti, G., and Rosa, D. D. (2006). Regulation, competition and productivity convergence. OECD Economics Department Working Papers (Number 509), OECD Publishing.

Czernich, N., Falck, O., Kretschmer, T., Woessmann, L. (2009). Broadband infrastructure and economic growth. CESIFO Working paper n. 2861.

Dimelis, S. P., and Papaioannou, S. K. (2010). FDI and ICT effects on productivity growth: A comparative analysis of developing and developed countries. European Journal of Development Research, 22(1), 79-96.

Economides, N., and Himmelberg, C. P. (1995). Critical mass and network size with application to the US FAX Market. NYU Stern School of Business EC-95-11, http://ssrn.com/abstract=6858, http://dx.doi.org/10.2139/ssrn.6858.

Erumban, A. A., and Das, D. K. (2016). Information and communication technology and economic growth in India. Telecommunications Policy, 40(5), 412-431.

Freeman, C., and Soete, L. (1994). Work for all or mass unemployment? Computerized technical change into the twenty-first century. UK: London Printer.

Freeman, C., and Soete, L. (1997). The economics of industrial innovation (3 ${ }^{\text {rd }}$ ed.). UK: London and Washington Printer.

Freeman, C., and Soete, L. (1985). Information technology and employment: An assessment. SPRU. Sussex, UK. 
INTERNATIONAL JOURNAL OF ACADEMIC RESEARCH IN BUSINESS AND SOCIAL SCIENCES

Vol. 8, No. 12, Dec, 2018, E-ISSN: 2222-6990 @ 2018 HRMARS

Gordon, R. (1999). Has the "New Economy" Rendered productivity paradox obsolete? Northwetern University and NBER, Cambridge, MA.

Gruber, H., and Koutroumpis, P. (2011). Mobile telecommunications and the impact on economic development. Economic Policy, 26(67), 387-426.

Gruber, H., and Koutroumpis, P. (2010). Mobile communications: Diffusion facts and prospects. Communication and Strategy, 77, 133-145.

GSMA (2016). The Mobile Economy. Sub Saharan African 2017. Retrieved from: https://www. Gsmaintelligence.com/research/?file=7bf3592e6d750144e58d9dcfac6adfab.

International Telecommunication Union (ITU). (2012). Measuring information society report. Geneva. Retrieved from https://www.itu.int/en/ITUD/Statistics/.../mis2012/MIS2012_ without _ Annex_4.pdf.

International Telecommunication Union (ITU). (2014). Measuring information society report. Geneva. Retrieved from: http://www.itu.int/en/ITUD/Statistics/Documents /publications /mis2014 / MIS2014_without_Annex_4.pdf.

International Telecommunication Union (ITU). (2015). Measuring Information Society Report.Geneva.retrievedhttp://www.itu.int/en/ITU/D/Statistics/Documents/publications/mi sr2015/MISR2015-w5.pdf.

Jin, S., and Cho, C. M. (2015). Is ICT a new essential for national economic growth in an information society? Government Information Quarterly, 32(3), 253-260.

Jorgenson, D. W., Ho, M. S., and Stiroh K. J. (2002). Projecting the productivity growth: Lessons from the U.S. growth resurgence. Federal Reserve Bank of Atlanta Economic Review, 3, 1-13.

Jorgenson, D. W., Ho, M. S., and Stiroh, K. J. (2005). Information technology and the American growth resurgence, Cambridge MIT Press.

Jorgenson, D. W. (2001). Information technology and the US economy. American Economic Review, 91(1), 1-32.

Jorgenson, D. W., and Vu, K. (2016). Information technology and the world economy. Scandinavian Journal of Economics, 337-348. doi:10.1057/9780230226203.080.

Katz, M., and Shapiro, K. (1986). Technology adoption in the presence of network externalities. The Journal of Political Economy, 94(4).

Koutroumpis, P. (2009). The economic impact of broadband on growth: A simultaneous approach. Telecommunications Policy, 33, 471-485.

Kpodar, K., and Andrianaivo, M. (2011). ICT, financial inclusion, and growth evidence from African countries. IMF Working Papers, 11(73), 1. doi:10.5089/9781455227068.001.

Kumar, R. R., Stauvermann, P. J., and Samitas, A. (2015a). The effects of ICT on output per worker: A study of the Chinese economy. Telecommunications Policy, 40(2-3),102-115. http://dx.doi.org/10.1016/j.telpol.2015.06.004.

Lee, S. H., Levendis, J., and Gutierrez, L. (2012). Telecommunications and economic growth: An empirical analysis of Sub-Saharan Africa. Applied Economics, 44(4), 461-469.

Loveman, G. (1988). An assessment of the productivity impact of information technologies. MIT Management in the 1990s (Working Paper, no. 88). 
INTERNATIONAL JOURNAL OF ACADEMIC RESEARCH IN BUSINESS AND SOCIAL SCIENCES

Vol. 8, No. 12, Dec, 2018, E-ISSN: 2222-6990 @ 2018 HRMARS

Mačiulytė-Šniukienè, A., and Gaile-Sarkane, E. (2014). Impact of information and telecommunication technologies development on labour productivity. Procedia-Social and Behavioral Sciences, 110, 1271-1282.

Mohyiden, J. M., Ismail, N. W., and Law, S. H. (2012). A Pooled Mean Group estimation on ICT infrastructure and economic growth in ASEAN-5 countries. International Journal of Economics and Management, 6(2), 360-378.

Manochehri, N., Al-Esmail, R., and Ashrafi, R. (2012). Examining the impact of information and communication technologies (ICT) on enterprise practices: A preliminary perspective from Qatar. The Electronic Journal of Information Systems in Developing Countries, 51.

Papaioannou, S., and Dimelis, S. (2007). Information technology as a factor of economic development: Evidence from developed and developing countries. Economics of Innovation and New Technology, 16(3): 179-194.

Roach, S. S. (1991). Services under siege: The restructuring imperative. Harvard Business Review, 39(2), 82-92.

Roach, S. S. (1987). America's technology dilemma: A profile of the information economy. Morgan Stanley spatial economic study (April): New York.

Samoilenko, S., and Osei-Bryson, K. (2008). An exploration of the effects of the interaction between ICT and labor force on economic growth in transition economies. International Journal of Production Economics, 115(2), 471-481. doi: 10.1016/j.ijpe.2008.07.002.

Sassi, S., and Goaied, M. (2013). Financial development, ICT diffusion and economic growth: Lessons from MENA region. Telecommunications Policy, 37(4-5), 252-261. doi: 10.1016/j.telpol.2012.12.004.

Solow, R. M. (1987). We'd Better Watch Out. New York Times Book Review, July 12: 36.

Solow R. M. (1957). Technical Change and the Aggregate Production Function. The Review of Economics and Statistics, 39(3): 312-320.

Solow, R. M. (1956) A contribution to the theory of economic growth, Quarterly Journal of Economics, 70(1), 65-94.

Tarutè, A., and Gatautis, R. (2014). ICT impact on SMEs performance. Procedia-Social and Behavioral Sciences, 110, 1218-1225.

Van Reenen, J., Bloom, N., Draca, M., Kretschmer, T., Sadun, R., Overman, H., and Schankerman, M. (2010). The economic impact of ICT. Final Report for the European Commission.

$\mathrm{Vu}, \mathrm{K} . \mathrm{M}$. (2011). ICT as a source of economic growth in the information age: Empirical evidence from the 1996-2005 period. Telecommunications Policy, 35(4), 357-372.

$\mathrm{Vu}$, K. M. (2013). Information and communication technology (ICT) and Singapore's economic growth. Information Economics and Policy, 25(4), 284-300.

Wamboye, E., Tochkov, K., and Sergi, B. S. (2015). Technology adoption and growth in Sub-Saharan African Countries. Comp Econ Stud Comparative Economic Studies, 57(1), 136-167. doi:10.1057/ces.2014.38.

Ward, M. R., and Zheng, S. (2016). Mobile telecommunications service and economic growth: Evidence from China. Telecommunications Policy, 40(2-3), 89-101. 
INTERNATIONAL JOURNAL OF ACADEMIC RESEARCH IN BUSINESS AND SOCIAL SCIENCES

Vol. 8, No. 12, Dec, 2018, E-ISSN: 2222-6990 @ 2018 HRMARS

Yousefi, A. (2011). The impact of information and communication technology on economic growth: evidence from developed and developing countries. Economics of Innovation and New Technology, 20(6), 581-596.

Zhen-Wei Qiang, C., Pitt, A., and Ayers, S. (2003). Contribution of information and communication technologies to growth. (World Bank Working Paper No. 24). http://dx.doi.org/10.1596/08213-5722-0. 